plants per annum. Initially conventional techniques will be used but consideration is being given to the production of container grown stock in a greenhouse.

They are also proposing a 540-acre forest fertilization experiment in cooperation with the Department of Forestry and Rural Development. Urea fertilizer will be applied at the rate of 92 pounds of nitrogen per acre in alternately fertilized and unfertilized strips.

\title{
FOR THE SAKE OF ARGUMENT
}

\section{PLANT THEM WIDE, GEORGE}

Discussion in the first three 1966 issues of the Chronicle, concerning "George's" role in spacing and timber production, included a comment by Cayford (June issue) that we need more quantitative data of the productivity of species at various spacings. A recent publication gives just this information. Yield tables for plantation white spruce (Picea glauca (Moench) Voss), described by Stiell and Berry (1967) ${ }^{1}$, showed the greatest volume production was attained from stands with the closest spacing. Love and Williams (1966) ${ }^{2}$ recommended white spruce be managed in Ontario for pulpwood, with no intermediate cuttings, and a suggested spacing of $8^{2}$ feet, i.e. $8 \times 8$ feet. Advocates of close spacing, "full" site use, and maximum yield will indignantly point out that volume production is being sacrificed. Too true, but this sacrifice can be offset by planting more acres, and this is economically superior--producing more volume per dollar.

Using the stand growth data of Stiell and Berry, which will favour the supporters of close spacing as much as is biologically possible assuming no thinnings, and a few economic assumptions, a series of calculations reveals the benefits of wider spacing.

Assumptions (1): that trees cost 1c each to buy and plant; an interest rate of $5 \%$ be used; site index is 70 feet 40 years after planting; value per cubic foot of timber does not vary with tree size. Costs not affecting the comparison between spacings, such as beating-up, weeding, maintenance, protection and taxation, have been excluded. Given in Table $1 \mathrm{Col}$. (1) are the merchantable (bole to a $4^{\prime \prime}$ top d.i.b.) yields at ages 20,25 , and 40 years from planting, of plantations initially spaced at $4^{2}, 5^{2}, 6^{2}, 7^{2}$, and $8^{2}$ feet. The extra volumes, in

${ }^{2}$ STIELL, W. M. and A. B. BERRY. 1967. White spruce plantation growth and yield at the Petawawa Forest Experiment Station. Can. Dep. For., For. Br., Departmental Public. No. 1200. 15 pp.

'LOVE, D. V. and J. R. M. WILLIAMS. 1966. The economics of plantation forestry in Southern Ontario. A.R.D.A. and Fac. of For., Univ. of Toronto Mimeo Report. $115 \mathrm{pp}$. 
excess of those from $8^{2}$ spacing, are given in Column (2). Compounded costs from planting and the differences with the basic $8^{2}$ spacing costs are given in Cols. (3) and (4) respectively. In Column (5) is the cost per cubic foot, and in Column (6) is the cost per cubic foot of the extra volume produced at closer spacings.

TABLE 1

Merchantable Volumes and COSTS Per ACRe, and Costs Per Unit Volume for Plantations at Ages 20, 25, and 40 Years Originally Planted at 4, 5, 6, 7, and 8 Feet Square Spacing. Original Costs 1c per Tree, INTEREST RATE 5\%, AND VoluMES FROM STIELl AND BERRY (1967) FOR S.I. 70.

\begin{tabular}{|c|c|c|c|c|c|c|c|c|}
\hline $\begin{array}{c}\text { Spacing } \\
\text { feet }\end{array}$ & $\begin{array}{l}\text { Original } \\
\text { stocking } \\
\text { stems/ac. }\end{array}$ & $\begin{array}{c}\text { Age from } \\
\text { planting } \\
\text { years }\end{array}$ & (1) & (2) & (3) & $\begin{array}{r}\text { Columns } \\
\text { (4) }\end{array}$ & (5) & (6) \\
\hline $4 \times 4$ & 2722 & 20 & 1058 & 307 & 72.22 & 54.15 & 0.068 & 0.176 \\
\hline $5 \times 5$ & 1742 & & 949 & 198 & 46.22 & 28.15 & 0.049 & 0.142 \\
\hline $6 \times 6$ & 1210 & & 868 & 117 & 32.10 & 14.04 & 0.037 & 0.120 \\
\hline $7 \times 7$ & 889 & & 797 & 46 & 22.59 & 4.52 & 0.028 & 0.098 \\
\hline $8 \times 8$ & 681 & & 757 & - & 18.07 & - & 0.024 & - \\
\hline $4 \times 4$ & 2722 & 25 & 2076 & 476 & 98.18 & 68.91 & 0.044 & 0.145 \\
\hline $5 \times 5$ & 1742 & & 1957 & 357 & 58.99 & 35.93 & 0.030 & 0.106 \\
\hline $6 \times 6$ & 1210 & & 1800 & 200 & 40.97 & 17.91 & 0.023 & 0.090 \\
\hline $7 \times 7$ & 889 & & 1698 & 98 & 30.10 & 7.04 & 0.018 & 0.072 \\
\hline $8 \times 8$ & 681 & & 1600 & - & 23.06 & - & 0.014 & - \\
\hline $4 \times 4$ & 2722 & 40 & 5079 & 627 & 191.63 & 143.69 & 0.038 & 0.229 \\
\hline $5 \times 5$ & 1742 & & 5010 & 558 & 122.64 & 74.69 & 0.024 & 0.134 \\
\hline $6 \times 6$ & 1210 & & 4802 & 350 & 85.18 & 37.24 & 0.018 & 0.106 \\
\hline $7 \times 7$ & 889 & & 4616 & 164 & 62.58 & 14.64 & 0.014 & 0.089 \\
\hline $8 \times 8$ & 681 & & 4452 & - & 47.94 & - & 0.011 & - \\
\hline
\end{tabular}

Column (1) is merchantable volume per acre, cubic feet all trees to a top d.i.b. of 4 inches.

(2) is merchantable volume per acre greater than that of $8 \times 8$ spacing.

(3) is initial costs compounded to date in dollars ner acre.

(4) is initial costs compounded to date greater than those for $8 \times 8$ spacing in dollars per acre.

(5) is cost per unit volume in dollars, Cols. (3)/(1)

(6) is cost per unit volume in dollars of extra praduction, Cols. (4)/(2).

With reference to Table 1 , at age 40, 4,452 cubic feet per acre can be produced at an average cost of 1.1 cents per cubic foot (excluding costs cited above). Planting at $7^{2}$ instead of $8^{2}$ results in an extra 164 cubic feet per acre, whereas at $4^{2}$ the extra production is 627 cubic feet per acre. The extra volume produced at $4^{2}$ spacing has cost $\$ 143.69$, or 22.9 cents per cubic foot. For the same sum of money we could get $143.69 / 0.011$, or 13,063 cubic feet of timber at $8^{2}$ planting. Not true, as we must take into account the cost of the extra land and management required. The 627 cubic feet could have been grown on $627 / 4,452$, or 0.141 acres, in a 40 -year-old plantation at $8^{2}$ spacing. This wood costs $\$ 6.75$, leaving $\$ 136.94$ to pay for this small acreage, clear it, pay the taxes, extra maintenance and protection, and allow for possible greater distances from a mill. With land costs averaging $\$ 12.20$ per acre in southern Ontario, and ranging up to $\$ 50.00$ per acre on high quality land 
(Love and Williams, 1966) ${ }^{2}$, this extra acreage seems economically attainable. If $7^{2}$ spacing is compared to $8^{2}$, the extra $\$ 14.47$ must pay the extra costs of the required 0.04 acres for $8^{2}$ spacing.

Assumptions (2): all factors as assumptions (1) but costs increased to 2c per tree, which might be achievable only with machine planting. This doubles all costs and the value of wider spacings is increased. An arithmetic progressive increase in costs is found with regular increased plant and planting costs.

Assumptions (3): all factors as assumptions (1) but the interest rate is raised, and this results in a geometrical progressive increase in costs. At the $8 \%$ rate, comparable volume and values as were given in Table 1 , are given in Table 2 for age 40 only, with a S.I. of 70 . Our extra 627 cubic feet per acre from $4^{2}$ spacing has now cost $\$ 443.40$, and at $8^{2}$ spacing this volume only costs $\$ 20.84$, leaving $\$ 422.56$ to pay for the extra acreage and associated costs!

Assumptions (4): all factors as assumptions (1) but with S.I. reduced to 40. Production at age 40 for S.I. 40 is identical to production of S.I. 70 at age 25 (see Table 1). The extra 476 cubic feet per acre from $4^{2}$ spacing has cost $\$ 191.63$ (cost difference at age 40 ), but this volume would have only cost $\$ 14.28$ at $8^{2}$ spacing (from $476 \times(1,600 / 47.94)$ ), leaving $\$ 177.35$ to finance the extra 0.30 acres required.

TABLE 2

Merchantable Volumes and Costs Per ACre, and Costs per unit Volume for Plantations at Age 40 Originally Planted at 4, 5, 6, 7, and 8 Feet Square Spacing. Original Costs of 1C Per Tree, Interest Rate at $8 \%$, AND Volumes from Stiell aNd BerRy (1967) FOR S.I. 70.

\begin{tabular}{|c|c|c|c|c|c|c|c|c|}
\hline $\begin{array}{c}\text { Spacing } \\
\text { feet }\end{array}$ & $\begin{array}{l}\text { Original } \\
\text { stocking } \\
\text { stems/ac. }\end{array}$ & $\begin{array}{c}\text { Are from } \\
\text { planting } \\
\text { years }\end{array}$ & (1) & (2) & (3) & $\begin{array}{r}\text { Columng } \\
(4) \\
\end{array}$ & (5) & (6) \\
\hline $4 \times 4$ & 2722 & 40 & 5079 & 627 & 591.34 & 443.40 & 0.116 & 0.707 \\
\hline $5 \times 5$ & 1742 & & 5010 & 558 & 378.44 & 230.50 & 0.076 & 0.413 \\
\hline $6 \times 6$ & 1210 & & 4802 & 350 & 262.87 & 114.92 & 0.055 & 0.328 \\
\hline $7 \times 7$ & 889 & & 4616 & 164 & 193.13 & 45.19 & 0.042 & 0.118 \\
\hline $8 \times 8$ & 681 & & 4452 & - & 147.94 & - & 0.033 & 一 \\
\hline
\end{tabular}

Column (1) is merchantable volume per acre, cubic feet all trees to a top d.i.b. of 4 inches.

(2) is merchantable volume per acre greater than that of $8 \times 8$ spacing.

(3) is initial costs compounded to date in dollars per acre.

4) is initial costs compounded to date greater than those for $8 \times 8$ spacing in dollars per acre.

(5) is cost per unit volume in dollars, Cols. (3)/(1).

(6) is cost per unit volume in dollars of extra production, Cols. (4)/(2).

Assumptions (5): all factors as assumptions (1) but value per unit volume increases with tree size. Average d.b.h. ranges from 4.0 inches at $4^{2}$ spacing, through 4.3 at $5^{2}$, up to 5.6 inches at $8^{2}$ at age 40 for S.I. 40 , and from 7.5 $\left(4^{2}\right)$ to $8.6\left(8^{2}\right)$ for S.I. 70 (Stiell and Berry, 1967) ${ }^{1}$. The increased value per unit volume may not be paid, but there is a related reduced cost of harvesting, as was mentioned by Baskerville in the afore-mentioned discussion (March issue). The harvesting and milling techniques currently in operation are linear, and therefore the less lineal feet per unit volume the less the operating time. Stiell and Berry did not cite any effect of spacing upon height at a given age. 
The number of trees (merchantable bole) required to produce 1 cunit at age 40 from a plantation of S.I. 70 is 11.6 from $8^{2}$ spacing, and 16.6 from $4^{2}$ spacing. If the plantation is only of S.I. 40, the numbers required are 42.2 and 92.5 respectively. The harvesting of the closer spaced plantations is therefore more expensive because the lineal footage processed to yield one cunit from a plantation at $4^{2}$ is twice that from one at $8^{2}$. Obviously, land is cheaper than growing-stock as a wood-producing machine.

George, if you remain unconvinced by these quantitative data take a look at Wardle's $(1967)^{3}$ assessment of advantages and disadvantages of wider spacing. Then you may want to consider even $12^{2}$.

${ }^{3}$ WARDLE, P. A. 1967. Spacing in plantations. Forestry XL (1) : 47-69.

\section{J. E. OSBORN}

Graduate STUdent

FACULTY OF FORESTRY

UNIVERSITY OF BRITISH COLUMBIA. 